\title{
Marker Assisted Breeding to Develop Multiple Stress Tolerant Varieties for Flood and Drought Prone Areas
}

\author{
Nitika Sandhu' ${ }^{1,2}$, Shalabh Dixit ${ }^{1}$, B. P. M. Swamy ${ }^{1}$, Anitha Raman', Santosh Kumar ${ }^{3}$, S. P. Singh ${ }^{4}$, R. B. Yadaw ${ }^{5}$, \\ O. N. Singh ${ }^{6}$, J. N. Reddy ${ }^{6}$, A. Anandan ${ }^{6}$, Shailesh Yadav ${ }^{1}$, Challa Venkataeshwarllu', Amelia Henry', Satish Verulkar ${ }^{8}$, \\ N. P. Mandal ${ }^{9}$, T. Ram $^{10}$, Jyothi Badri ${ }^{10}$, Prashant Vikram ${ }^{1,11}$ and Arvind Kumar ${ }^{1 *}$ (D)
}

\begin{abstract}
Background: Climate extremes such as drought and flood have become major constraints to the sustainable rice crop productivity in rainfed environments. Availability of suitable climate-resilient varieties could help farmers to reduce the grain yield losses resulting from the climatic extremities. The present study was undertaken with an aim to develop high-yielding drought and submergence tolerant rice varieties using marker assisted introgression of $9 D T Y_{1.1}, q D T Y_{2.1}, q D T Y_{3.1}$ and Sub1. Performance of near isogenic lines (NILs) developed in the background of Swarna was evaluated across 60 multi-locations trials (MLTs). The selected promising lines from MLTs were nominated and evaluated in national trials across 18 locations in India and 6 locations in Nepal.

Results: Grain yield advantage of the NILs with $q D T Y_{1.1}+q D T Y_{2.1}+q D T Y_{3.1}+S u b 1$ and $q D T Y_{2.1}+q D T Y_{3.1}+$ Sub1 ranged from 76 to $2479 \mathrm{~kg} \mathrm{ha}^{-1}$ and 396 to $2376 \mathrm{~kg} \mathrm{ha}^{-1}$ under non-stress (NS) respectively and 292 to $1118 \mathrm{~kg}$ $\mathrm{ha}^{-1}$ and 284 to $2086 \mathrm{~kg} \mathrm{ha}^{-1}$ under reproductive drought stress (RS), respectively. The NIL, IR96322-34-223-B-1-1-11 having $9 D T Y_{1.1}+q D T Y_{2.1}+q D T Y_{3.1}+$ Sub1 has been released as variety CR dhan 801 in India. IR 96321-1447-651-B1-1-2 having $9 D T Y_{1.1}+9 D T Y_{3.1}+$ Sub 1 and IR 94391-131-358-19-B-1-1-1 having $9 D T Y_{3.1}+$ Sub1 have been released as varieties Bahuguni dhan-1' and 'Bahuguni dhan-2' respectively in Nepal. Background recovery of 94\%, 93\% and 98\% was observed for IR 96322-34-223-B-1-1-1-1, IR 96321-1447-651-B-1-1-2 and IR 94391-131-358-19-B-1-1-1 respectively on $6 \mathrm{~K}$ SNP Infinium chip.

Conclusion: The drought and submergence tolerant rice varieties with pyramided multiple QTLs can ensure 0.2 to $1.7 \mathrm{t} \mathrm{ha}^{-1}$ under reproductive stage drought stress and 0.1 to $1.0 \mathrm{t} \mathrm{ha}^{-1}$ under submergence conditions with no yield penalty under non-stress to farmers irrespective of occurrence of drought and/or flood in the same or different seasons.
\end{abstract}

Keywords: Drought, Marker-assisted breeding, QTL pyramiding, Rice, Submergence, Varieties

\section{Background}

Increasing incidences of abiotic stresses under changing climate are major constraints to meet the ever-growing demand for food for rapidly escalating population and attain the global food security (Lesk et al. 2016). Drought and flood are the two most prevalent abiotic stresses reducing rice yield in the rainfed environments.

\footnotetext{
* Correspondence: a.kumar@irri.org

${ }^{1}$ International Rice Research Institute, DAPO Box 7777, Metro Manila, Philippines

Full list of author information is available at the end of the article
}

Worldwide, drought and flood stresses have been reported to affect approximately 40 million hectares of total rice area at different crop stages producing negative impacts on plant growth, development and yield (Barnabás et al. 2008; Neeraja et al. 2007). Rainfed rice ecosystems in South Asia and Southeast Asia are the key hotspots for the occurrence of combination of drought and flood stresses (Dilley et al. 2005). High rainfall over short period during crop growth or low rainfall or early withdrawal of monsoon rains may bring flood or prolonged dry spell causing substantial reduction to crop yields (Lobell et al. 
2011). Many times, both flood and drought may occur in the same season at different crop growth stages. In the coming years rainfed shallow lowland areas will face heavy precipitation during early crop growth stage leading to flood, and then dry period leading to drought at terminal stages. Variability in the pattern, intensity and frequency of rainfall with the changing climate are several of the factors leading to unpredictable occurrence of drought and flood conditions. These adverse conditions are causing crop failures, volatility in economic growth and making it harder for the small and marginal farmers to move up from the persistent poverty (Mottaleb et al. 2015).

In Nepal, about $50 \%$ and in India more than $33 \%$ of the total cropland is dedicated to cultivation of rice (Pandey and Bhandari 2007; Gumma et al. 2011). Large area in the rainfed rice-growing ecologies India and Nepal are vulnerable to submergence and drought (Dar et al. 2014). More than 7.3 and 0.27 million hectares of rainfed lowland rice ecologies in India and Nepal respectively, are affected by drought stress (Pandey and Bhandari 2008). Over 5 million hectares of rice land in India is prone to submergence, leading to a paddy loss of 4 million tons per year which is otherwise enough to provide food to 30 million people (Mottaleb et al. 2015).

The rice varieties such as Swarna, Samba Mahsuri, IR64 and MTU1010 are popular among the farmers in India because of their high yield, preferred grain quality traits and higher market value. However, most of these rice varieties are extremely sensitive to drought and submergence, leading to high yield losses every year in regions of their cultivation. The traditional varieties cultivated before the development of semi-dwarf green revolution varieties are less sensitive to drought and flood but poor in yield and grain quality. Introgression of drought and flood tolerance into existing popular rice varieties has been an effective approach to cope with the effects of drought and submergence and reduce yield losses under drought and flood.

In past few decades, efforts have been devoted at the International Rice Research Institute (IRRI) in identifying major genes/QTLs (Kumar et al. 2014), developing selection strategies (Kumar et al. 2018) and understanding the genetics of grain yield under drought in rice (Sandhu and Kumar 2017). Major effect drought QTLs explaining large proportion of the phenotypic variance for grain yield such as $q D T Y_{1.1}$ (Vikram et al. 2011; Ghimire et al. 2012; Sandhu et al. 2014), $q D T Y_{2.1}$ (Venuprasad et al. 2009; Sandhu et al. 2014) and $q D T Y_{3.1}$ (Dixit et al. 2014; Venuprasad et al. 2009) have been identified. These QTLs in synergistic combinations of two to three together can provide grain yield advantage of 0.8 to $1.0 \mathrm{tha}^{-1}$ under reproductive stage drought stress (Sandhu and Kumar 2017).
A major effect QTL Sub1 from a landrace FR13A explaining phenotypic variation of 69\% (Xu and Mackill 1996; Septiningsih et al. 2015) providing tolerance to two weeks of complete submergence has also been identified. The submergence tolerance of many mega varieties such as Swarna (Neeraja et al. 2007), Ciherang (Septiningsih et al. 2015; Toledo et al. 2015) and PSB Rc18 (Septiningsih et al. 2015) were improved using marker-assisted backcross breeding of Sub1.

The rice varieties combining drought and submergence can provide yield insurance to farmers in regions exposed to occurrence of drought or submergence or both in the rainfed ecosystems. In this study, the strategy of marker assisted backcross selection in the early stages combined with phenotypic selection at later stage of development has been followed. The present study was conducted with the aim to develop the drought-submergence tolerant near-isogenic lines (NILs) in the background of Swarna combining high yield under non-stress, drought and submergence conditions with preferred grain quality traits. The objectives of the present study include (1) to introgress $q D T Y_{1.1}, q D T Y_{2.1}$ and $q D T Y_{3.1}$ with Sub1 in the background of Swarna (2) to study the interactions between the drought QTLs and Sub1 in terms of performance under drought or submergence when introgressed together (3) to study the performance of breeding lines with different combinations of DTY QTLs and Sub1 on grain yield under reproductive stage drought stress (RS), submergence stress (Sub) and non-stress conditions (NS).

\section{Results}

\section{Single trial analysis}

The developed NILs were screened at IRRI and in national trials in India (Hyderabad, Sabour, Faizabad, Madhepura, Dhangain, Patna, Varanasi, Tripura, Cuttack and Raipur) and Nepal (Hardinath and Nepalgunj). A total of 60 multi-locations experiments were conducted (Additional file 1: Table S1). The mean grain yield ranged from 2037 to $9848 \mathrm{~kg} \mathrm{ha}^{-1}$ under NS (non-stress), 175 to $6739 \mathrm{~kg}$ $\mathrm{ha}^{-1}$ under RS (reproductive stage drought stress) and 1278 to $8068 \mathrm{~kg} \mathrm{ha}^{-1}$ under submergence conditions (Additional file 1: Table S1). The days to $50 \%$ flowering (DTF) ranged from 83 to 116 days under NS, 85 to 118 days under RS and 83 to 128 under submergence conditions. The plant height varied from 84 to $110 \mathrm{~cm}$ under NS, 54 to $99 \mathrm{~cm}$ under RS and 74 to $115 \mathrm{~cm}$ under submergence conditions (Additional file 1: Table S1).

\section{Performance of Swarna lines introgressed with drought and submergence QTLs}

The NILs in Swarna background with either single or multiple QTL produced grain yield advantage over Swarna (Additional file 1: Table S2; Fig. 1). The NILs with $q D T Y_{1.1}+q D T Y_{2.1}+q D T Y_{3.1}+$ Sub1 and $q D T Y_{2.1}+$ 

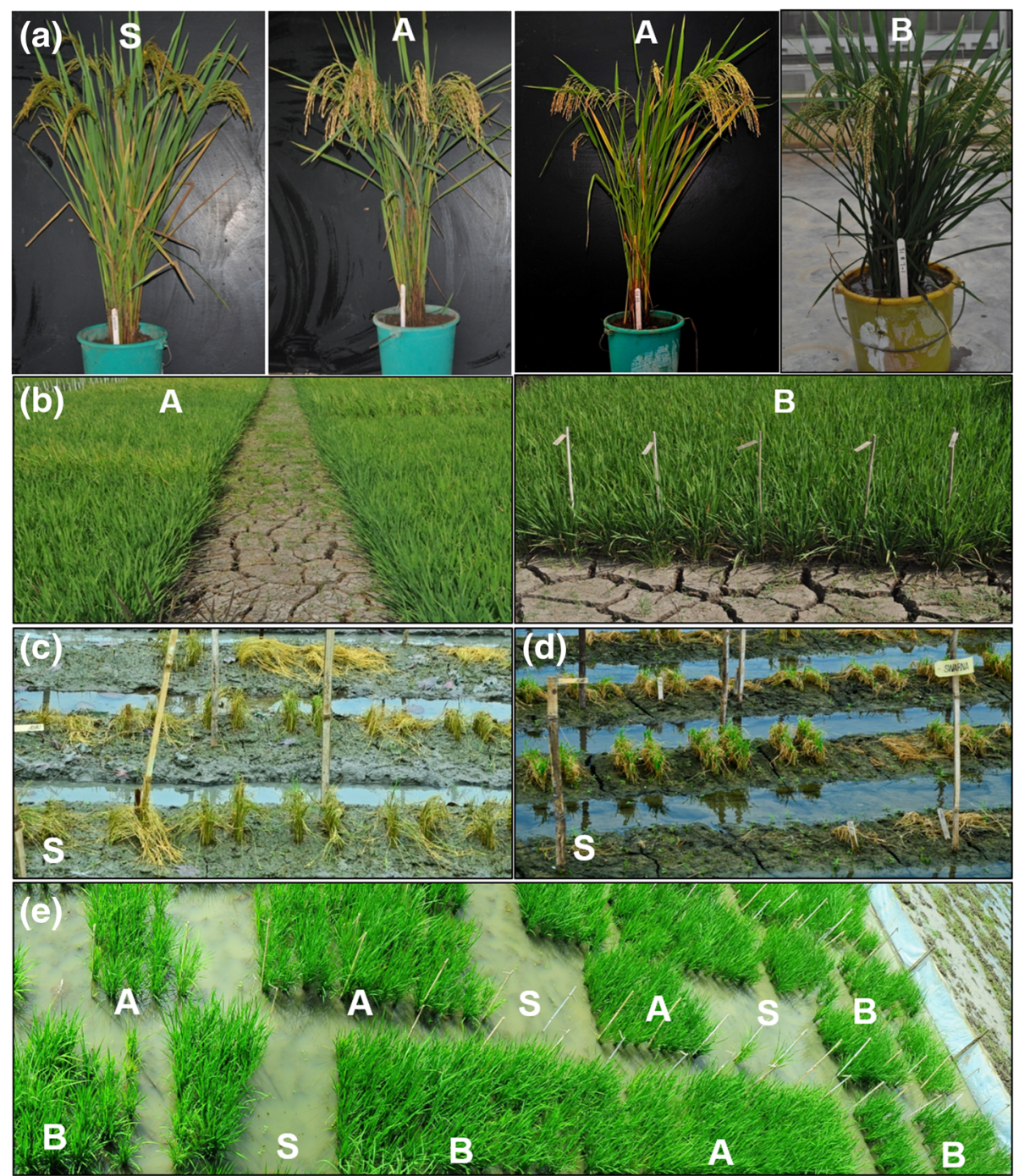

Fig. 1 a The morphological differences between Swarna and introgressed NILs; b field view of introgressed NILs under reproductive stage drought stress condition; submergence tolerance of introgressed NILs compared to Swarna (c) one day after draining; $\mathbf{d}$ six day after draining; e recovery of introgressed NILs compared to Swarna one month after draining. S: Swarna, A: introgressed NIL with $9 D T Y_{21}+9 D T Y_{31}+S_{1} b_{1} \mathrm{~B}$ : introgressed NIL with $q D T Y_{1.1}+9 D T Y_{2.1}+9 D T Y_{3.1}+$ Sub1

$q D T Y_{3.1}+$ Sub1 showed grain yield advantage that ranged from 76 to $2479 \mathrm{~kg} \mathrm{ha}^{-1}$ and 396 to $2376 \mathrm{~kg} \mathrm{ha}^{-1}$ over Swarna under NS respectively. Grain yield advantage of 292 to $1118 \mathrm{~kg} \mathrm{ha}^{-1}$ and 284 to $2086 \mathrm{~kg} \mathrm{ha}^{-1}$ was observed in $q D T Y_{1.1}+q D T Y_{2.1}+q D T Y_{3.1}+$ Sub1 and $q D T Y_{2.1}+$ $q D T Y_{3.1}+$ Sub1 NILs respectively over Swarna under RS (Additional file 1: Table S2). The grain yield advantage of NILs having $q D T Y_{1.1}+q D T Y_{3.1}+$ Sub1 QTL combination ranged from 37 to $1350 \mathrm{~kg} \mathrm{ha}^{-1}$ and 95 to $629 \mathrm{~kg} \mathrm{ha}^{-1}$ over Swarna under NS and RS, respectively. In addition, the two QTL classes $\left(q D T Y_{1.1}+q D T Y_{2.1}+q D T Y_{3.1}+S u b 1\right.$ and $\left.q D T Y_{2.1}+q D T Y_{3.1}+S u b 1\right)$ showed consistently higher performance than other QTL classes under both NS and RS across advancing generations (Additional file 1: Table S2).
The NILs with days to $50 \%$ flowering less than that of Swarna and Swarna-Sub1 under NS and RS were identified (data not shown). Most of the NILs showed similar plant height as that of Swarna and Swarna-Sub1 under NS and less under RS (data not shown).

\section{QTL × environment}

The variance component for QTL $\times$ environment interaction was significant at all stress levels; non-stress, moderate drought stress and severe drought stress. A significant environment variance component was observed in the case of non-stress experiments. The QTL main effect was significant only under severe drought stress (Table 1). 
Table 1 The mixed model (REML) parameters of the combined analysis for all three stresses levels

\begin{tabular}{llll}
\hline Stress & Cov Parm & Estimate & $\operatorname{Pr}>$ Z \\
\hline Non-stress & QTL & 69,808 & 0.0594 \\
& environment & $2,802,695$ & 0.0007 \\
& QTL × environment & 231,386 & 0.0009 \\
& Residual & 585,608 & $<.0001$ \\
Moderate drought stress & QTL & 5971.56 & 0.4548 \\
& environment & 136,417 & 0.1539 \\
& QTL × environment & 1418.58 & 0.4891 \\
& Residual & 428,228 & $<.0001$ \\
Severe drought stress & QTL & 107,741 & 0.0013 \\
& environment & 90,708 & 0.1047 \\
& QTL $\times$ environment & 68,940 & 0.0099 \\
& Residual & 81,811 & $<.0001$ \\
Tests of (Fixed Effects) & & & \\
Stress & Effect & F Value & $\operatorname{Pr}>\mathrm{F}$ \\
Non-stress & QTL & 1.25 & 0.2468 \\
Moderate drought stress & QTL & 1.16 & 0.4285 \\
Severe drought stress & QTL & 1.64 & 0.0781 \\
\hline
\end{tabular}

The selected NILs showed significant yield advantage over recipient parent Swarna under reproductive stage drought indicating capture of positive interaction between QTL $\times$ QTL or QTL $\times$ genetic background utilizing strategy combining genotypic and phenotypic selection for grain yield under NS and RS.

\section{Performance of Swarna NILs with different QTL combinations across different locations}

The tested NILs across all location and trials (Additional file 1: Table S1) were pooled together and categorised based on QTL combinations into three different stress levels; non-stress, moderate drought stress and severe drought stress. The NILs with $q D T Y_{1.1}+q D T Y_{2.1}+$ $q D T Y_{3.1}+\operatorname{Sub1}, q D T Y_{1.1}+q D T Y_{3.1}+\operatorname{Sub1}$ and $q D T Y_{3.1}$ + Sub1 had shown consistent grain yield advantage across different locations and seasons (Table 2).

\section{Selection of promising NILs}

Seeds of the selected promising lines (48 lines in 2014WS) were multiplied and shared with NARES (National Agricultural Research and Extension Systems) partners for further screening across multi locations under NS, RS and submergence conditions. The selected NILs showed grain yield advantage over both Swarna and Swarna-Sub1 under NS, RS and submergence stress conditions. Under NS and RS, IR 94391-131-358-19-B-1-1-1 showed highest grain yield advantage followed by IR 96322-34-223-B-1-1-1 and IR 96322-34-127-B-1-1-1 over Swarna (Table 3). Similar pattern of grain yield advantage was observed for NILs over Swarna-Sub1 under NS and RS (Table 3). The three selected promising NILs had shown grain yield advantage ranged from 109 to $2382 \mathrm{~kg} \mathrm{ha}^{-1}$ over Swarna and 99 to $2448 \mathrm{~kg} \mathrm{ha}^{-1}$ over Swarna-Sub1 under NS (Table 3). Under RS, the grain yield advantage of three selected promising NILs ranged from 415 to $1933 \mathrm{~kg} \mathrm{ha}^{-1}$ over Swarna and 38 to $1786 \mathrm{~kg} \mathrm{ha}^{-1}$ over Swarna-Sub1 (Table 4). The selected NILs had shown consistent performance across different locations and seasons. Under submergence conditions, the NIL IR 94391-131-358-19-B-1-1-1 had shown highest grain yield advantage followed by IR 96322-34-127-B-1-1-1 and IR 96322-34-223-B-1-1-1 over Swarna and Swarna-Sub1 both.

In addition, other NILs such as IR 96321-1447651-B-1-1-2, IR 96321-558-563-B-2-1-3 and IR 94391-131-358-19-B-6-1-4 had shown grain yield advantage that ranged from 72 to $1600 \mathrm{~kg} \mathrm{ha}^{-1}, 155$ to $1556 \mathrm{~kg}$ $\mathrm{ha}^{-1}$ and 38 to $828 \mathrm{~kg} \mathrm{ha}^{-1}$ over Swarna-Sub1, respectively under RS (Table 4). The promising NILs had shown better survival percentage over Swarna-Sub1 under 13 and 21 days of submergence. The survival percentage ranged from 83 to $96 \%$ after 14 days of submergence period and 75 to $92 \%$ after 21 days of submergence (Table 5).

\section{Performance of selected NILs under national trials}

The selected nine promising lines were nominated under All India Co-ordinated Rice Improvement Program (AICRIP) in India and in Nepal for varietal release. The 156 polymorphic SSRs markers were used to study the percentage background recovery of selected nine promising lines. The percentage background recovery ranged from 89 to $98 \%$ (Tables 3, 4 and 5). In addition, out of the nine selected lines, 5 promising lines with good performance over locations (IR 96321-1447-651-B-1-1-2, IR 96322-34-223-B-1-1-1, IR 96321-558-257-B-5-1-2, IR 96321-558-563-B-2-1-3 and IR 96322-34-127-B-1-1-1) were genotyped using $6 \mathrm{~K}$ SNP chip. Among these five, IR 96322-34-223-B-1-1-1-1 in India and IR 94391131-358-19-B-1-1-1 and IR 96321-1447-651-B-1-1-2 in Nepal have been released/identified for release as varieties. The graphical representation of the allelic distribution of the three NILs released as varieties (IR 96322-34-223B-1-1-1-1, IR 96321-1447-651-B-1-1-2 and IR 94391-131-358-19-B-1-1-1) across 12 rice chromosomes is presented in Fig. 2. The performance of IR 9632234-223-B-1-1-1-1 in comparison with Swarna-Sub1 and Swarna across 2015WS and 2016WS at 18 different locations under NS, RS and submergence conditions in AICRIP is presented in Fig. 3. The Swarna-Sub1 NIL, IR 96322-34-223-B-1-1-1-1 having $q D T Y_{1.1}+q D T Y_{2.1}+$ $q D T Y_{3.1}+S u b 1$ has been released for cultivation in India in 2017 as variety under name 'CR dhan 801'. It has maturity duration of 125 to 130 days, suitable to be grown 
Table 2 The mean grain yield performance of Swarna NILs with different QTL combinations across different locations at three different stress levels

\begin{tabular}{|c|c|c|c|c|c|c|c|c|c|c|c|c|}
\hline \multirow[t]{2}{*}{ QTL } & \multicolumn{4}{|c|}{ Non-stress } & \multicolumn{4}{|c|}{ Moderate drought stress } & \multicolumn{4}{|c|}{ Severe drought stress } \\
\hline & $\begin{array}{l}\text { No of } \\
\text { entries }\end{array}$ & $\begin{array}{l}\text { No. of } \\
\text { observations }\end{array}$ & Mean & $\begin{array}{l}\text { Std } \\
\text { err }\end{array}$ & $\begin{array}{l}\text { No of } \\
\text { entries }\end{array}$ & $\begin{array}{l}\text { No. of } \\
\text { observations }\end{array}$ & Mean & $\begin{array}{l}\text { Std } \\
\text { err }\end{array}$ & $\begin{array}{l}\text { No of } \\
\text { entries }\end{array}$ & $\begin{array}{l}\text { No. of } \\
\text { observations }\end{array}$ & Mean & $\begin{array}{l}\text { Std } \\
\text { err }\end{array}$ \\
\hline$q D T Y_{1.1}+S u b 1$ & 5 & 24 & 6336 & 448.9 & 4 & 10 & 2355 & 248.0 & 5 & 9 & 1378 & 279.9 \\
\hline$q D T Y_{2.1}+S u b 1$ & 1 & 4 & 7217 & 640.6 & & & & & 1 & 2 & 1585 & 457. \\
\hline $9 D T Y_{3.1}$ & 3 & 11 & 7285 & 488.6 & 2 & 3 & 2903 & 368.3 & 3 & 6 & 1662 & 298. \\
\hline $9 D T Y_{3.1}+S u b 1$ & 6 & 39 & 6421 & 377.7 & 6 & 17 & 2502 & 334.7 & 6 & 14 & 1337 & 262. \\
\hline$q D T Y_{1.1}+q D T Y_{2.1}+S u b 1$ & 6 & 25 & 6633 & 432.0 & 3 & 7 & 2488 & 262.5 & 4 & 8 & 1426 & 312.2 \\
\hline$q D T Y_{1.1}+q D T Y_{3.1}+$ Sub 1 & 13 & 74 & 6403 & 396.3 & 10 & 24 & 2552 & 264.5 & 12 & 31 & 1201 & 216.3 \\
\hline$q D T Y_{2.1}+q D T Y_{3.1}+S u b 1$ & 4 & 26 & 6752 & 445.5 & 3 & 10 & 2558 & 282.6 & 4 & 10 & 1161 & 300. \\
\hline$q D T Y_{1.1}+q D T Y_{2.1}+q D T Y_{3.1}$ & 6 & 15 & 6798 & 461.7 & 3 & 3 & 2935 & 440.1 & 3 & 6 & 1134 & 331.5 \\
\hline$q D T Y_{1.1}+q D T Y_{2.1}+q D T Y_{3.1}+S u b 1$ & 20 & 86 & 6711 & 388.1 & 9 & 18 & 2902 & 256.2 & 11 & 20 & 1599 & 239. \\
\hline Swarna-Sub1 & 1 & 68 & 6112 & 422.3 & 1 & 8 & 1678 & 332.1 & 1 & 21 & 882 & 255.2 \\
\hline
\end{tabular}

Total number of times entries tested in different trials across locations and seasons, Std err standard error

under shallow to medium lowland areas, have short bold grain type, plant height of 80 to $98 \mathrm{~cm}$, and an average yield of 5.0 to $5.5 \mathrm{tha}^{-1}$.

The performance of IR 94391-131-358-19-B-1-1-1 and IR 96321-1447-651-B-1-1-2 in comparison with SwarnaSub1 in 2014WS and 2015WS at 6 different locations in Nepal under NS in national trials is shown in Fig. 4a. The performance of IR 94391-131-358-19-B-1-1-1 and IR 96321-1447-651-B-1-1-2 in comparison with Swarna and Swarna-Sub1 in 2015WS at Hardinath under NS, RS and Submergence conditions is presented in Fig. 4b. The Swarna-Sub1 NILs, IR 96321-1447-651-B-1-1-2 having $q D T Y_{1.1}+q D T Y_{3.1}+$ Sub 1 and IR 94391-131-358-19B-1-1-1 having $q D T Y_{3.1}+$ Sub 1 have been released as varieties in Nepal in 2017 under name 'Bahuguni dhan-1' and 'Bahuguni dhan-2', respectively. Both these varieties have maturity duration of 130 to 135 days, plant height of 95 to $105 \mathrm{~cm}$, and shown average grain yield of 4.5 to $5.5 \mathrm{tha}^{-1}$. The grain quality parameters of released varieties in comparison to Swarna and Swarna-Sub1 are presented in Table 6. Bahuguni Dhan 1 is fine grain and Bahuguni Dhan 2 has medium grain type as Swarna. The background recovery of $94 \%, 93 \%$ and $98 \%$ was observed for IR 96322-34-223-B-1-1-1-1, IR 96321-1447-651-B-1-1-2 and IR 94391-131-358-19-B-1-1-1, respectively on $6 \mathrm{~K}$ SNP Infinium chip.

\section{Discussion}

Farmers in drought and submergence prone areas are mainly cultivating the abiotic stress susceptible rice varieties primarily due to their good grain yield potential and market-driven grain quality traits. The performance of these varieties is generally good during the nondrought-submergence affected years (Dar et al. 2018).
However, during the natural calamities, large reduction in grain yield is observed in these varieties due to their inability to survive and yield under drought or submergence or both. Some of the rice growing regions are equally vulnerable to both drought and submergence. There is a need to look at the problem of farmers in a holistic way to improve the resilience of farmer's livelihood so that food and other basic needs can be met on a sustainable basis. Development of dual flood and drought tolerant rice varieties lead to the overall increase in the farm output, farmer's income and will improve the livelihood systems of rice farming communities.

The introduction of marker-assisted breeding in agriculture has provided new opportunities towards the introgression of identified trait associated genes/ QTLs in several popular rice varieties (Dixit et al. 2017; Shamsudin et al. 2016). The grain yield advantage over Swarna and Swarna-Sub1 under RS drought stress and submergence, of those NILs possessing earlier identified major and consistent-effect QTLs, $q D T Y_{1.1}$ (Vikram et al. 2011; Ghimire et al. 2012; Sandhu et al. 2014), $q D T Y_{2.1}$ (Venuprasad et al. 2009; Sandhu et al. 2014), $q D T Y_{3.1}$ (Dixit et al. 2014; Venuprasad et al. 2009) and Sub1 (Neeraja et al. 2007) in the current marker-assisted backcrossing breeding programs indicates the suitability of these loci in improving drought-submergence tolerance in the Swarna background. In addition, the selected NILs showed significant grain yield advantage under NS as the selection for grain yield under both NS and RS was made across generation advancement. IR 96322-34223-B-1-1-1 showed grain yield advantage of 2 to $54 \%$ under NS (Table 3) and 1 to $17 \%$ under moderate to severe drought stress (Table 4) over the combined 


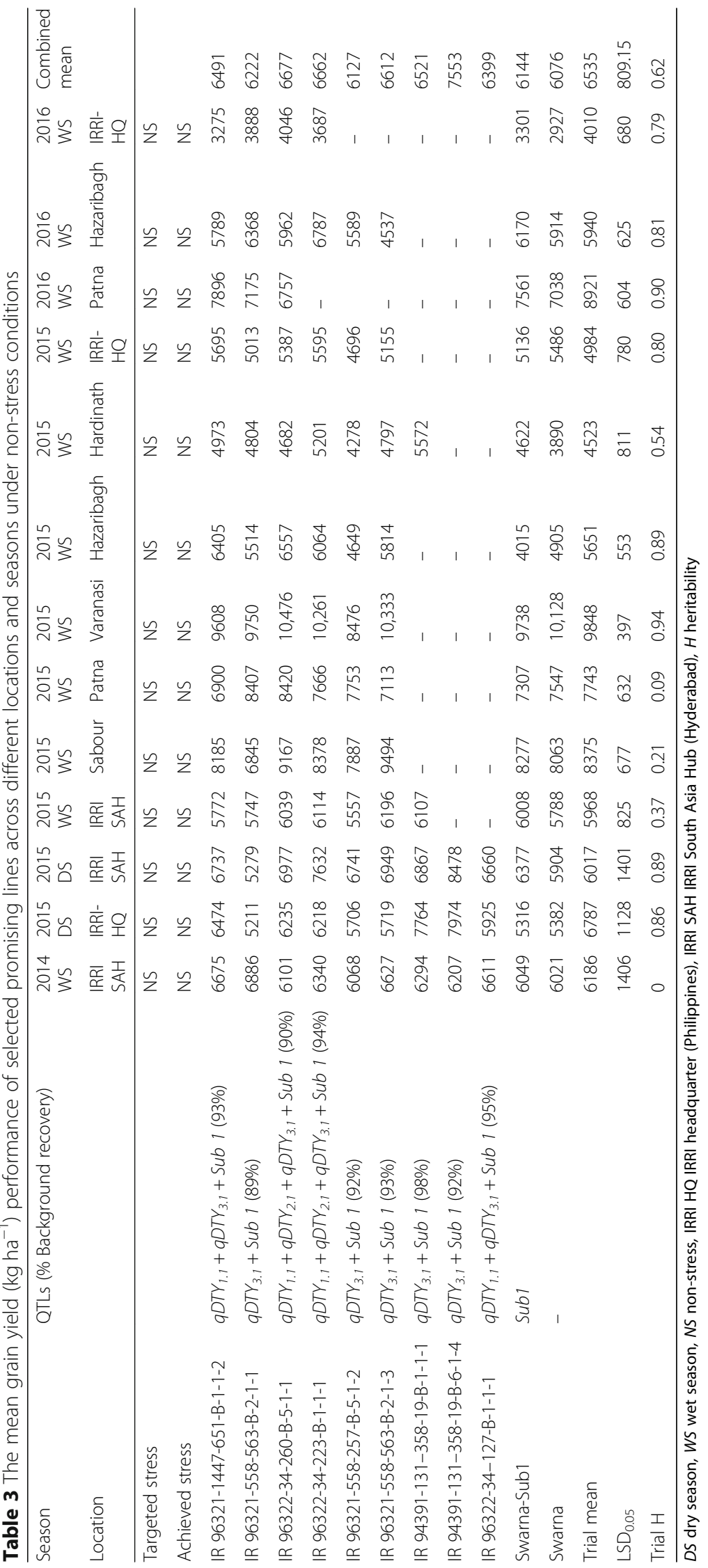


Table 4 The mean grain yield $\left(\mathrm{kg} \mathrm{ha}^{-1}\right.$ ) performance of selected promising lines across different locations and seasons under moderate and severe reproductive stage drought stress (RS) and submergence conditions (Sub)

\begin{tabular}{|c|c|c|c|c|c|c|c|c|c|c|c|c|c|}
\hline Season & QTLS & $\begin{array}{l}2014 \\
\text { WS }\end{array}$ & $\begin{array}{l}2015 \\
\text { WS }\end{array}$ & $\begin{array}{l}2015 \\
\text { WS }\end{array}$ & $\begin{array}{l}2014 \\
\text { WS }\end{array}$ & $\begin{array}{l}2015 \\
\text { DS }\end{array}$ & $\begin{array}{l}2016 \\
\text { WS }\end{array}$ & $\begin{array}{l}2016 \\
\text { WS }\end{array}$ & $\begin{array}{l}2014 \\
\text { WS }\end{array}$ & $\begin{array}{l}2014 \\
\text { WS }\end{array}$ & Combined & mean & \multirow{4}{*}{ Sub } \\
\hline Location & & Hardinath & Patna & Hardinath & Hardinath & IRRI-HQ & Raipur & $\begin{array}{l}\text { Nepal } \\
\text { gunj }\end{array}$ & $\begin{array}{l}\text { Hardi } \\
\text { nath }\end{array}$ & $\begin{array}{l}\text { Nepal } \\
\text { gunj }\end{array}$ & & & \\
\hline $\begin{array}{l}\text { Targeted } \\
\text { stress }\end{array}$ & & NS & RS & RS & RS & RS & RS & RS & Sub & Sub & \multicolumn{2}{|l|}{ RS } & \\
\hline $\begin{array}{l}\text { Achieved } \\
\text { stress }\end{array}$ & & $\begin{array}{l}\text { Moderate } \\
\text { drought } \\
\text { stress }\end{array}$ & $\begin{array}{l}\text { Moderate } \\
\text { drought } \\
\text { stress }\end{array}$ & $\begin{array}{l}\text { Moderate } \\
\text { drought } \\
\text { stress }\end{array}$ & $\begin{array}{l}\text { Severe } \\
\text { drought } \\
\text { stress }\end{array}$ & $\begin{array}{l}\text { Severe } \\
\text { drought } \\
\text { stress }\end{array}$ & $\begin{array}{l}\text { Severe } \\
\text { drought } \\
\text { stress }\end{array}$ & $\begin{array}{l}\text { Severe } \\
\text { drought } \\
\text { stress }\end{array}$ & Sub & Sub & $\begin{array}{l}\text { Moderate } \\
\text { drought } \\
\text { stress }\end{array}$ & $\begin{array}{l}\text { Severe } \\
\text { drought } \\
\text { stress }\end{array}$ & \\
\hline $\begin{array}{l}\text { IR 96321- } \\
\text { 1447-651- } \\
\text { B-1-1-2 }\end{array}$ & $\begin{array}{l}q D T Y_{1.1}+q D T Y_{3.1}+ \\
\text { Sub } 1 \text { (93\%) }\end{array}$ & 2799 & 3796 & 3300 & 1155 & 1525 & 836 & 909 & 1351 & 763 & 3298 & 1106 & 1057 \\
\hline $\begin{array}{l}\text { IR 96321- } \\
558-563- \\
\text { B-2-1-1 }\end{array}$ & $\begin{array}{l}9 D T Y_{3.1}+5 u b 1 \\
(89 \%)\end{array}$ & 2306 & 3542 & 2033 & 1298 & 1635 & 1681 & 763 & 1664 & 1379 & 2627 & 1344 & 1522 \\
\hline $\begin{array}{l}\text { IR 96322- } \\
34-260- \\
\text { B-5-1-1 }\end{array}$ & $\begin{array}{l}q D T Y_{1.1}+q D T Y_{2.1}+ \\
q D T Y_{3.1}+\text { Sub }_{1} \\
(90 \%)\end{array}$ & 2378 & 2359 & 1100 & 1110 & 1758 & 1236 & 1539 & 1151 & 715 & 1946 & 1411 & 933 \\
\hline $\begin{array}{l}\text { IR 96322- } \\
34-223- \\
\text { B-1-1-1 }\end{array}$ & $\begin{array}{l}q D T Y_{1.1}+q D T Y_{2.1}+ \\
q D T Y_{3.1}+\text { Sub }_{1} \\
(94 \%)\end{array}$ & 3068 & 3589 & 2600 & 1105 & 1566 & 1361 & - & 1383 & 1359 & 3086 & 1344 & 1371 \\
\hline $\begin{array}{l}\text { IR 96321- } \\
558-257- \\
\text { B-5-1-2 }\end{array}$ & $\begin{array}{l}q D T Y_{3.1}+\text { Sub } 1 \\
(92 \%)\end{array}$ & 2548 & 2017 & 2333 & 845 & 1679 & - & - & 1105 & 1532 & 2299 & 1262 & 1319 \\
\hline $\begin{array}{l}\text { IR 96321- } \\
558-563- \\
\text { B-2-1-3 }\end{array}$ & $\begin{array}{l}q D T Y_{3.1}+\text { Sub } 1 \\
(93 \%)\end{array}$ & 2393 & 3383 & 2800 & 1163 & 2077 & - & - & 1662 & 1087 & 2859 & 1620 & 1375 \\
\hline $\begin{array}{l}\text { IR 94391- } \\
\text { 131-358- } \\
\text { 19-B-1-1-1 }\end{array}$ & $\begin{array}{l}9 D T Y_{3.1}+\text { Sub } 1 \\
(98 \%)\end{array}$ & 3390 & - & 2900 & 1405 & 2307 & - & - & 1989 & 1311 & 3145 & 1856 & 1650 \\
\hline $\begin{array}{l}\text { IR 94391- } \\
\text { 131-358- } \\
19-B-6-1-4\end{array}$ & $\begin{array}{l}9 D T Y_{3.1}+\text { Sub } 1 \\
(92 \%)\end{array}$ & 3133 & - & - & 1133 & 1870 & - & - & 1500 & - & 3133 & 1502 & 1500 \\
\hline $\begin{array}{l}\text { IR 96322- } \\
\text { 34-127- } \\
\text { B-1-1-1 }\end{array}$ & $\begin{array}{l}q D T Y_{1.1}+q D T Y_{3.1}+ \\
\text { Sub } 1(95 \%)\end{array}$ & 2221 & - & - & 1103 & 1349 & - & - & 1650 & - & 2221 & 1226 & 1650 \\
\hline $\begin{array}{l}\text { Swarna- } \\
\text { Sub1 }\end{array}$ & Sub1 & 2183 & 2658 & 1700 & 1008 & 521 & 764 & 789 & 1081 & 1154 & 2180 & 771 & 1118 \\
\hline Swarna & - & 1457 & 2739 & 1867 & 688 & 755 & 684 & 575 & 173 & 150 & 2021 & 676 & 162 \\
\hline $\begin{array}{l}\text { Trial } \\
\text { mean }\end{array}$ & & 2447 & 2987 & 2353 & 1072 & 1510 & 1267 & 792 & 1290 & 1231 & 2596 & 1160 & 1261 \\
\hline $\mathrm{LSD}_{0.05}$ & & 1437 & 709 & 908 & 340 & 585 & 425 & 630 & 320 & 554 & 887 & 554 & 437 \\
\hline Trial H & & 0.53 & 0.92 & 0.63 & 0.52 & 0.81 & 0.95 & 0.64 & 0.36 & 0.40 & 0.69 & 0.73 & 0.38 \\
\hline
\end{tabular}

DS dry season, WS wet season, NS non-stress, RS reproductive stage drought stress, Sub Submergence stress DS dry season, IRRI HQ IRRI headquarter (Philippines), $H$ heritability

mean across seasons and locations. IR 94391-131358-19-B-1-1-1 showed grain yield advantage of 5 to $19 \%$ under NS (Table 3 ) and 8 to $24 \%$ under moderate to severe drought stress (Table 4) over the combined mean across seasons and locations. Similarly, IR 94391131-358-19-B-1-1-1 showed grain yield improvement of 3 to $48 \%$ under NS (Table 3 ) and 4 to $38 \%$ under moderate to severe drought stress (Table 4) over the combined means across seasons and locations. The improvement of 0.8 to $1.0 \mathrm{t} \mathrm{ha}^{-1}$ in the yield of pyramided lines in different backgrounds as reported earlier (Vandana, IR64, MTU1010, TDK1, and MRQ74) (Kumar et al. 2014; Sandhu and Kumar 2017) as well as in the current study validates the success of QTL introgression in improving grain yield and tolerance to multiple stresses. The developed NILs were previously shown to perform well across different severity/intensity of drought and in regions with different conditions/ soil types (Singh et al. 2017). Some of the selected NILs showed early days to flowering than Swarna under NS (data not shown) and this may have 
Table 5 Survival percentage (\%) of NILs screened at Patna in 2015DS under submergence conditions

\begin{tabular}{llll}
\hline Designation & $\begin{array}{l}\text { Background } \\
\text { recovery (\%) }\end{array}$ & Survival \% & \\
\hline & & 14 days $^{\text {a }}$ & 21 days $^{\text {a }}$ \\
IR 96321-315-323-B-3-1-3 & 93 & 96 & 82 \\
IR 96321-315-323-B-3-1-1 & 93 & 90 & 82 \\
IR 96321-558-209-B-6-1-1 & 98 & 83 & 82 \\
IR 96321-558-257-B-4-1-2 & 91 & 92 & 92 \\
IR 96321-1099-227-B-3-1-3 & 90 & 94 & 89 \\
IR 96321-558-563-B-2-1-3 & 95 & 87 & 75 \\
IR 96321-558-563-B-2-1-1 & 89 & 88 & 81 \\
Swarna Sub 1 & - & 85 & 54 \\
Swarna & - & 58 & 6 \\
LSD $_{0.05}$ & - & 7 & 26 \\
\hline
\end{tabular}

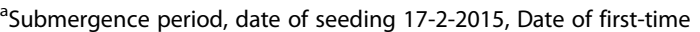
submergence 27-03-2015, date of de-submergence 09-04-2015, date of second time submergence 14-05-2015, Date of de-submergence 04-06-2015

resulted from the linkages of the qDTYs with earliness (Vikram et al. 2016). The plant height of most of the selected NILs were similar to the PHT of Swarna under NS but higher under RS (data not shown), this may be due to their increased ability to produce more biomass under RS. The linkage has been successfully broken and semi-dwarf, medium duration NILs in Swarna background have been developed.

QTL $\times$ environment interaction is a phenomenon in which QTL effects may significantly differ across environments. In the present study, the significant QTL $x$ environment interaction for all the stress levels and the release of varieties with different combinations of QTLs in different ecosystems indicating the role of environment in influencing the effect of QTLs. The expression of introgressed genomic loci affecting grain yield and yield contributing components is influenced by the environment and the same loci may have differential effects in different ecosystems, signifying strong QTL $\times$ environment interaction (Xing et al. 2002). In the present study, the differential performance of NILs with same QTL combination in same or different ecosystem could be due to unknown QTL $x$ genetic background interactions. There is urgent need to identify such epistatic gene interactions which complicates the genotype phenotype relationship of complex trait (Carlborg and Haley 2004) such as drought and submergence.

The phenotypic screening of NILs under different stresses; non-stress, drought stress and submergence conditions revealed huge variation among different combinations of QTLs. The selection of NILs outperforming under different intensities of multiple stresses allows the selection of lines with desirable characteristics. The selected lines with significantly high grain yield advantage over Swarna under both NS as well as RS captured positive interaction due to both genotypic and phenotypic selection practised in the present study, a strategy suggested to be followed in marker assisted breeding for abiotic stress tolerance till all such unknown interactions are identified. Revealing of such epistatic interactions, between introgressed QTL and genetic background sheds light in understanding the differential phenotypic expression of introgressed/pyramided lines for quantitative traits that can be useful in future marker-assisted selection programs.

In our study, across ecosystems in India and Nepal, Swarna and Swana-Sub1 showed similar performance under drought at majority of the locations as against Swarna-Sub1 reported to show higher performance over Swarna under drought (Fukao et al. 2011).

The release of marker-assisted breeding product for drought earlier in IR64 background (Sandhu and Kumar 2017) and now in the present study in Swarna-Sub1 background are successful examples that should encourage breeders to use QTLs in the breeding programs targeting grain yield improvement under abiotic stresses. This is one of the first studies in rice developing stable and high-yielding varieties combining both drought and submergence tolerance in a high yielding variety background through marker-assisted backcrossing breeding successfully released as varieties for cultivation by farmers. In the present study, we observed improved performance of selected NILs over Swarna and Swarna-Sub1 under drought and submergence but we are yet to evaluate the lines under varying incidences of subsequent submergence and drought in the same season and observe plants adaptation. Even after affected by submergence under which duration of varieties increases by 10-12 days, the developed NILs showed an average of 10 days earlier flowering than Swarna-Sub1. This will allow the timely planting of second season crop hence enhancing sustainable productivity. The yield improvement across three different backgrounds, TDK-Sub1 (Dixit et al. 2017), IR64-Sub1 (data not published) and SwarnaSub1 (present study) possessing both QTLs combining drought (DTYs) and submergence (Sub1) clearly indicates that the drought and submergence tolerance can be efficiently combined even though both have different molecular and physiological regulatory mechanisms. QTLs on grain yield under drought has been reported to effect water-uptake, stomatal conductance, canopy temperature, transpiration and root growth at depth (Henry et al. 2014, 2015) whereas the physiological evidence for the submergence tolerance points towards the proper balance between the production and consumption of plant assimilates (Singh et al. 2014; Kretzschmar et al. 2015), fast coleoptile elongation, 


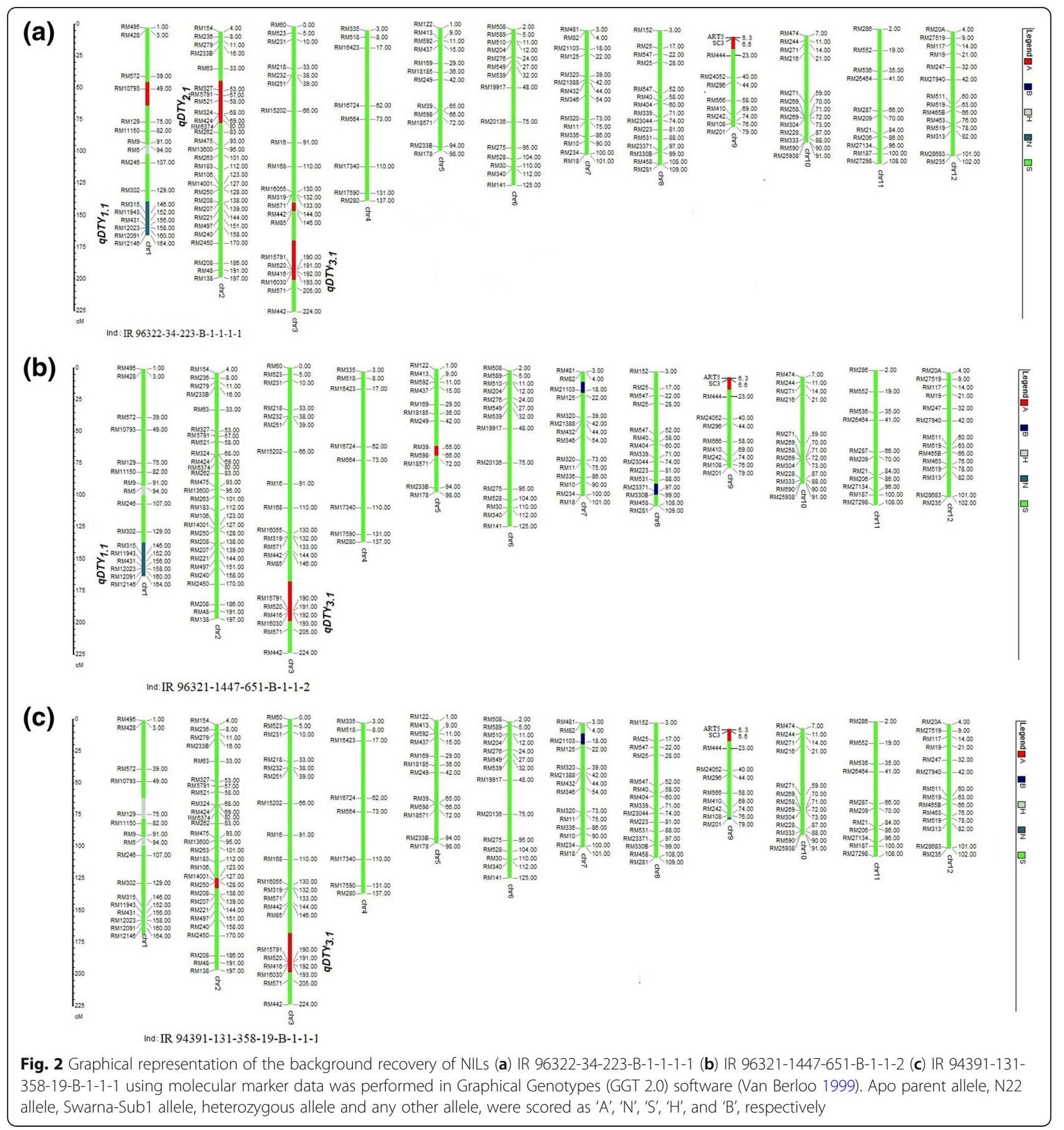

expansin genes expression, and lower cell division and peroxidase activity (Magneschi and Perrata 2009). "The development and release of three drought-submergence tolerant varieties (CR dhan 801, Bahuguni dhan-1 and Bahuguni dhan-2) for cultivation in rainfed lowland areas of India and Nepal are successful examples of contribution of use of genomic tools to improve yield under drought and submergence".

\section{Conclusions}

Over last one-decade marker assisted breeding for abiotic stress has moved from just improving yield under drought or submergence to combining high yield potential with good yield under multiple stresses. The nine selected promising NILs with different QTL combination showed an average grain yield advantage of 0.2 to $1.7 \mathrm{tha}^{-1}$ under RS and 0.1 to $1.0 \mathrm{tha}^{-1}$ under 

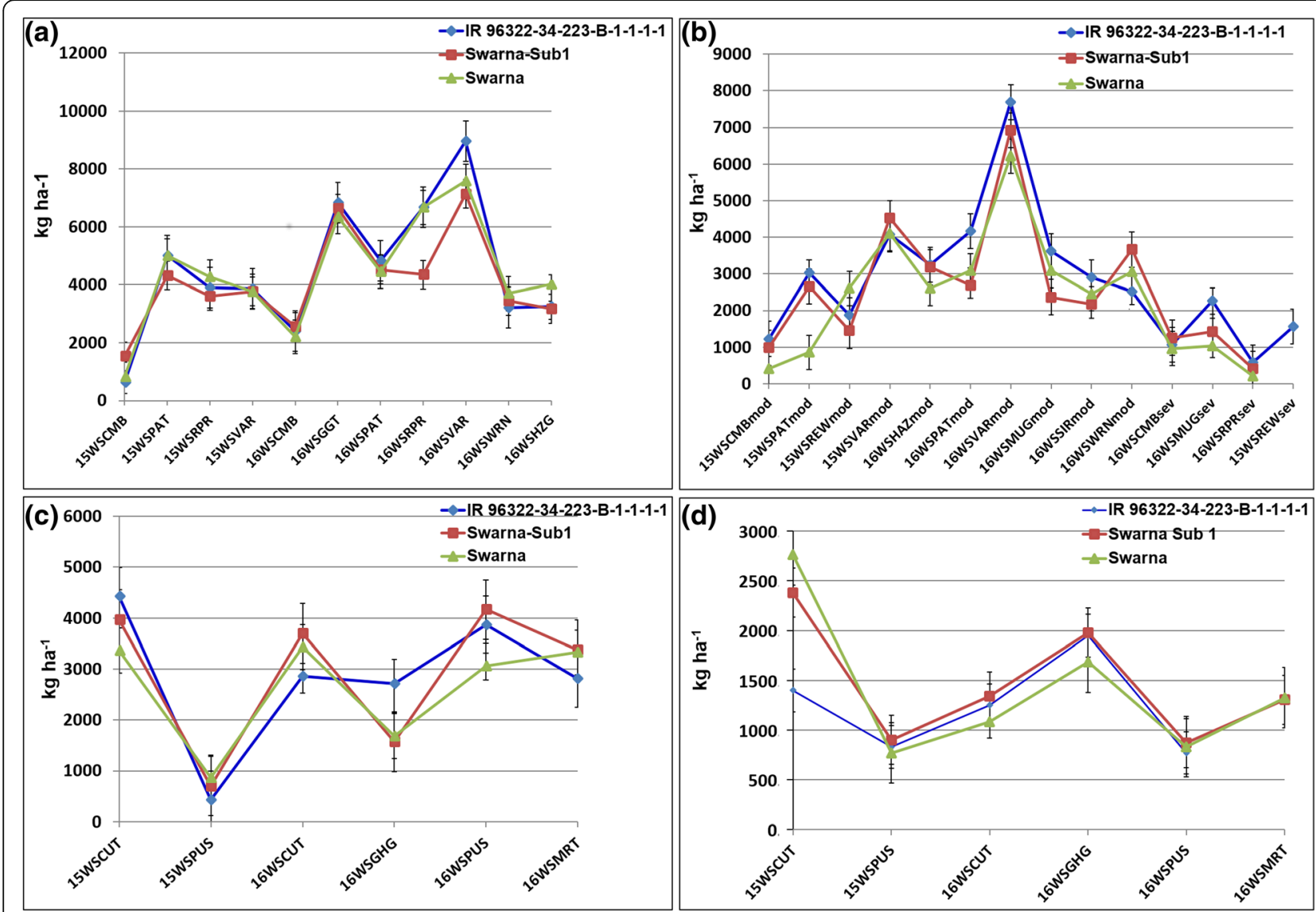

Fig. 3 The grain yield performance of IR 96322-34-223-B-1-1-1-1 in comparison with Swarna-Sub1 and Swarna (a) under NS \{control for RS\}; b under RS; c under NS \{control for Submergence\}; d under Submergence in 2015WS and 2016WS in different locations under AICRIP trials in India. CMB: Coimbatore, CUT: Cuttack, GGT: Ghaghraghat, HZG: Hazaribag, MUG: Mugad, MRT: Maruteru, PAT: Patna, PUS: Pusa, RPR: Raipur, REW: Rewa, SIR: Sirsi, VAR: Varanasi, WRN: Warangal, DS: dry season, WS: wet season, NS - non-stress, RS: reproductive stage drought stress, mod: moderate drought stress, sev: severe drought stress
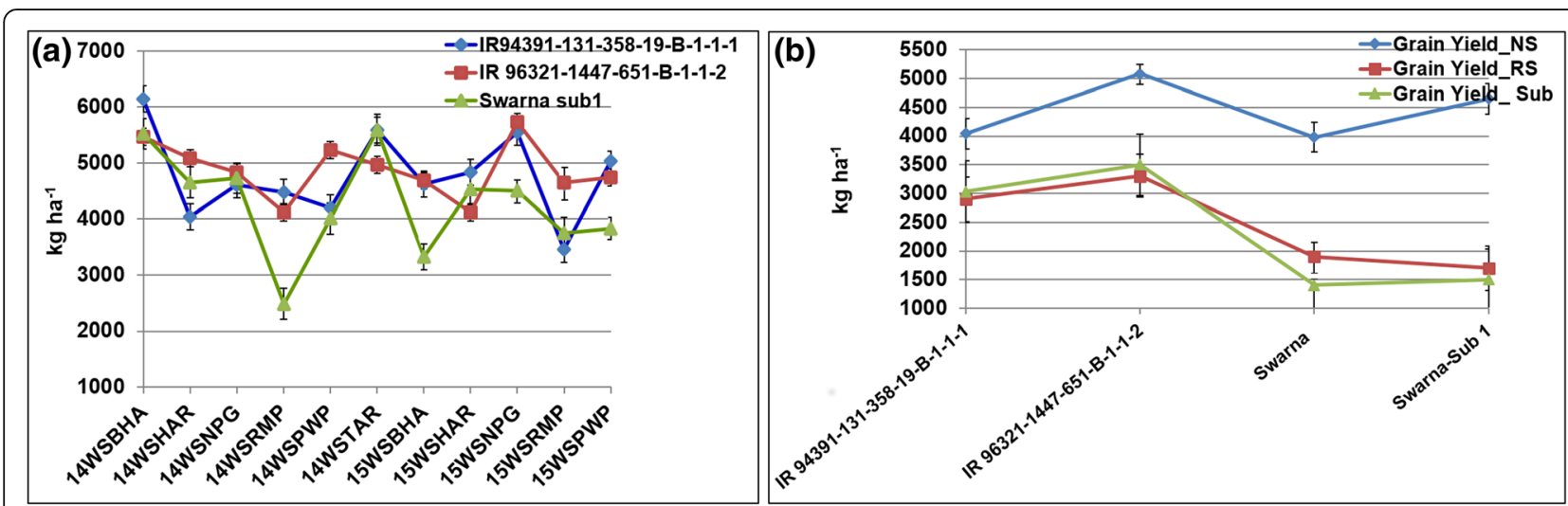

Fig. 4 The mean grain yield performance of NILs in comparison with (a) Swarna-Sub1 across multilocational trials in Nepal under NS; b Swarna and Swarna-Sub1 in 2015WS at Hardinath under NS, RS and submergence conditions. BHA: Bhairahawa; HAR: Hardinath; NPG: Nepalgunj; RMP: Rampur; PWP: Parwanipur; TAR: Tarahara NS: non-stress, RS: reproductive stage drought stress, Sub: Submergence. 
Table 6 Grain quality parameters of the varieties released in India and Nepal in Swarna background in 2017

\begin{tabular}{|c|c|c|c|c|c|c|c|c|c|c|c|}
\hline Designation & $\begin{array}{l}\text { Variety } \\
\text { name }\end{array}$ & Chalkiness & $\begin{array}{l}\text { Grain } \\
\text { length }\end{array}$ & $\begin{array}{l}\text { Grain } \\
\text { width }\end{array}$ & $\begin{array}{l}\text { Amylose } \\
\text { content }\end{array}$ & $\begin{array}{l}\text { Weight } \\
\text { milled } \\
\text { rice }\end{array}$ & $\begin{array}{l}\% \text { milled } \\
\text { rice }\end{array}$ & $\begin{array}{l}\text { Weight } \\
\text { head } \\
\text { rice }\end{array}$ & $\begin{array}{l}\% \text { head } \\
\text { rice }\end{array}$ & $\begin{array}{l}\text { Crude } \\
\text { Ash (\%) }\end{array}$ & $\begin{array}{l}\text { kjeldahl } \\
\mathrm{N}(\%)\end{array}$ \\
\hline IR 96322-34-223-B-1-1-1-1 & CR dhan 801 & 7.4 & 5.48 & 2.32 & 27.4 & 85.3 & 68.2 & 70.7 & 56.5 & - & - \\
\hline IR 96321-1447-651-B-1-1-2 & $\begin{array}{l}\text { Bahuguni } \\
\text { dhan-1 }\end{array}$ & 2.9 & 5.50 & 2.23 & 25.5 & 82.9 & 66.3 & 65.8 & 52.6 & 1.33 & 1.19 \\
\hline IR 94391-131-358-19-B-1-1-1 & $\begin{array}{l}\text { Bahuguni } \\
\text { dhan-2 }\end{array}$ & 1.8 & 5.69 & 2.34 & 26.9 & 86.9 & 69.5 & 75.3 & 60.2 & 1.31 & 1.17 \\
\hline Swarna-Sub1 & - & 3.2 & 5.76 & 2.23 & 26.8 & 82.9 & 66.3 & 73.5 & 58.8 & - & - \\
\hline Swarna & - & 3.9 & 5.58 & 2.29 & 27.9 & 82.1 & 65.6 & 71.1 & 56.8 & - & - \\
\hline
\end{tabular}

submergence conditions with no yield penalty under NS. The three drought-submergence tolerant varieties CR dhan 801, Bahuguni dhan-1 and Bahuguni dhan-2 have been released for cultivation in India and Nepal. The marker-assisted derived drought and submergence tolerant rice varieties will help to reduce the yield losses associated with farming in drought-flood prone rainfed lowland areas, provide farmers with insurance of good yield and shall encourage markerbreeding programs developing better varieties tolerant to multiple abiotic and biotic stresses.

\section{Material and methods}

\section{Plant material}

Swarna, the popular rice variety, (released in 1979) and cultivated in $30-40 \%$ of rainfed lowland areas $(\sim 4.3$ million ha) was chosen as a recipient to develop NILs using marker assisted backcrossing approach. Swarna-Sub1, the submergence tolerant NIL of Swarna was selected as the donor for Sub1 gene. This variety is a long duration (140145 days), medium-tall $(95-100 \mathrm{~cm})$, medium bold grain type with high tillering and an average yield of 6000-6200 $\mathrm{kg} \mathrm{ha}^{-1}$ was selected as donors for Sub1. Swarna-Sub1 provided yield advantage over Swarna under submergence condition. It has high head hulling percentage, high rice recovery and intermediate amylose content. Instead of traditional donors, advanced breeding lines possessing QTLs with high-yield potential were used in marker assisted breeding. IR 91659-54-35, an improved $\mathrm{BC}_{3} \mathrm{~F}_{3}$ breeding line from the mapping population N22/Swarna possessing $q D T Y_{1.1}$, IR 81896-B-B-195, an improved $\mathrm{BC}_{1} \mathrm{~F}_{5}$ line from Apo/Swarna population possessing $q D T Y_{2.1}$ and $q D T Y_{3.1}$ and Swarna-Sub1 possessing Sub1 gene were used in the marker-assisted backcrossing program to combine three drought QTLs and Sub1 gene in Swarna background.

\section{Development of NILs in Swarna-Sub1 background}

The crossing scheme to develop NILs in Swarna-Sub1 background was initiated in 2009DS (DS: dry season), the NIL IR 81896-B-B-195, an improved $\mathrm{BC}_{1} \mathrm{~F}_{5}$ line from
Apo/Swarna population possessing QTLs $q D T Y_{2.1}$ and $q D T Y_{3.1}$ was crossed with (Swarna-Sub1), $\mathrm{F}_{1}$ was two times backcrossed with IR05F102 (Swarna-Sub1). In 2010WS (WS: Wet season), a $\mathrm{BC}_{2} \mathrm{~F}_{1}$ plant possessing $q D T Y_{2.1}, q D T Y_{3.1}$ and Sub1 was crossed with IR 9165954-35, an improved $\mathrm{BC}_{3} \mathrm{~F}_{3}$ breeding line from the mapping population $\mathrm{N} 22 /$ Swarna possessing $q D T Y_{1.1}$. The backcrossed line IR 81896-B-B-195 used for introgression and pyramiding of $q D T Y_{2.1}, q D T Y_{3.1}$ QTLs came from the mapping population developed for identification of QTLs, from a crossing plan initiated in 2003DS (Fig. 5). The backcrossed line IR 91659-54-3-5 carrying $q D T Y_{1.1}$ was developed using N22 as donor, a crossing program initiated in 2007DS (Fig. 5). The detailed description on backcrossing, phenotypic plant selection, foreground, recombinant and background selection genotyping to identify NILs with desirable plant and grain type having introgressed QTLs is presented in Fig. 5. The markers linked to the QTLs targeted for introgression; $q D T Y_{1.1}$ (RM315, RM11943, RM431, RM12023, RM12091and RM12233),

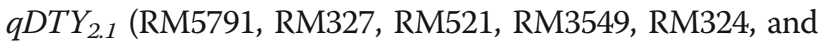
RM6374, RM424) and $q D T Y_{3.1}$ (RM15791, RM416, RM16030, RM520) and Sub1 (ART5, SC3) were used for foreground selection in Swarna background.

\section{Description on experiments and agronomic management}

The breeding lines were developed and screened under lowland transplanted control (non-stress; NS); lowland reproductive-stage drought stress conditions (RS) and seedling stage submergence condition (Sub). For evaluation of the introgressed lines and to identify the superior lines, a total of 60 experiments were conducted in Philippines (IRRI), Nepal (Hardinath, Nepalgunj) and India (Hyderabad, Sabour, Faizabad, Madhepura, Dhangain, Patna, Varanasi, Tripura, Cuttack, Hazaribagh and Raipur) from 2014DS to 2016WS. In all experiments each plot was 1 to 4 or more (advanced national trials) rows of 3 to $5 \mathrm{~m}$ plot length, with 0.20 $\mathrm{m}$ row-to-row spacing and $0.15-\mathrm{m}$ plant to plant spacing. Nursery bed was raised and 21 to 25-days old 


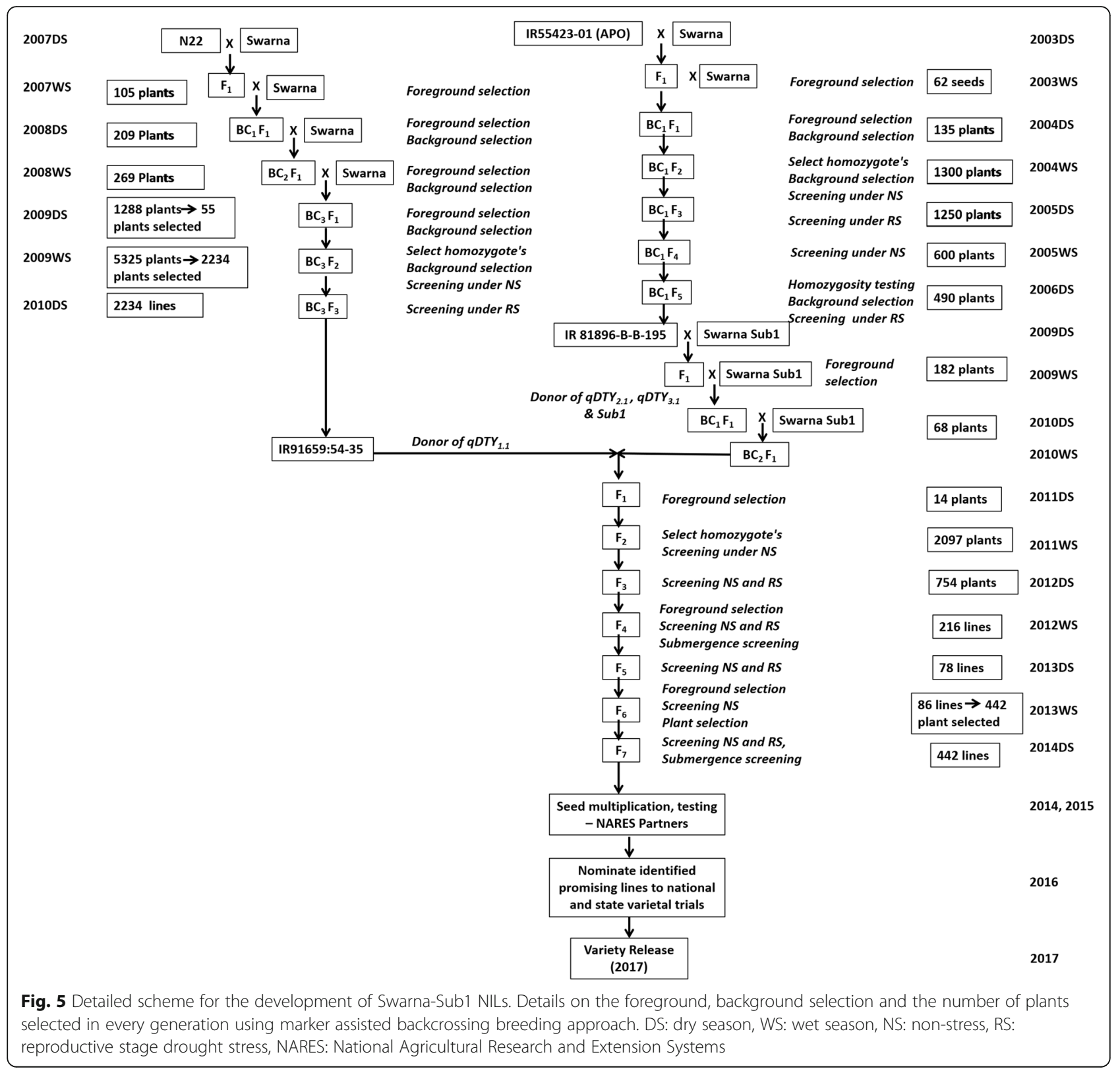

seedlings were transplanted. The agricultural management practices were followed as Vikram et al. (2011).

\section{Screening for reproductive stage drought stress}

The non-stress experiments were conducted under irrigated, flooded, puddled, transplanted, and anaerobic conditions with no drought and submergence stress. The reproductive-stage drought stress experiments referred to the experiments maintained as described by Sandhu et al. (2014). Depending on the site's ability to measure data, tensiometers (at $30 \mathrm{~cm}$ depth), water pipes (1.1 m length) were installed and rainfall data was recorded across different years (Additional file 1: Figure S1). These measurements were collected from
50 to 100 days after seeding (DAS), which approximately represents the reproductive stage of the NILs evaluated under reproductive stage drought stress. For the reproductive stage drought stress, the stress was initiated at 50-52 days after seeding, after which the drought stress treatment was maintained depending on the rainfall. When the tensiometers reading ranged from -50 to $-70 \mathrm{kPa}$, and the water table in PVC dropped to $100 \mathrm{~cm}$ from the soil surface and wilting and drying of leaves were observed (data not shown), the plots were re-irrigated. This cyclic screening at reproductive stage allows the precise screening of breeding lines with wide range of growth duration (Lafitte et al. 2004). 


\section{Screening for submergence tolerance}

The screening for submergence tolerance was carried out in Nepal (Hardinath, Nepalgunj) and India (Faizabad, Madhepura, Dhangain, Patna). The protocol for the screening for submergence tolerance was as described in Dixit et al. (2017). Selected NILs were planted in the nursery beds along with Swarna, Swarna-Sub1 and susceptible check IR42. The field was submerged for about two weeks from 14 days after seeding (DAS) to 27 days after seeding and then field was drained. The final recovery was recorded seven days after draining (Dixit et al. 2017). The tolerance to submergence was recorded on 1-9 scale of increasing order of susceptibility based on the standard evaluation system for submergence tolerance (IRRI 2002). In dry season, the submergence screening was conducted in a concrete tank facility. The selected lines were seeded in the seeding trays and at 14 DAS the trays were submerged along with IR42. The concrete tanks were drained on 30 DAS depending upon the survival of IR42, the susceptible check. The numbers of seedlings survived per line were recorded before submergence and at 2, 7, 14, and 21 days after draining the tanks, and percentage survival was calculated (Dixit et al. 2017). Survival percentage $=$ (number of seedling survived after submergence/total number of seedlings planted)*100.

\section{Phenotypic evaluation}

Key traits such as days to $50 \%$ flowering (DTF, days), plant height $(\mathrm{PHT}, \mathrm{cm})$, grain yield $\left(\mathrm{GY}, \mathrm{kg} \mathrm{ha}^{-1}\right)$ were measured and submergence was scored based on 1-9 scale. Days to $50 \%$ flowering referred to the day when more than $50 \%$ of the plants in plot showed panicle exertion. Plant height from root-shoot base to the highest panicle was recorded from three plants per plot and averaged. Grain yield data was recorded per plot and normalized for moisture content to $14 \%$ before final yield computation in $\mathrm{kg} \mathrm{ha}^{-1}$. Plant and panicle selections were made to get grain type similar to Swarna.

\section{Genotyping}

Genotyping work was carried out at GSL (Genotyping Service Laboratory); IRRI Genomic DNA was extracted from leaves of 21 days old seedling using modified CTAB method (Murray and Thompson 1980).

The polymorphic markers linked to $q D T Y_{1.1}$ (RM315, RM11943, RM431, RM12023, RM12091, RM12146 and RM12233; Vikram et al. 2011), $q D T Y_{2.1}$ (RM5791, RM327, RM521, RM3549, RM324, and RM6374, RM424; Venuprasad et al. 2009) and $q D T Y_{3.1}$ (RM15791, RM416, RM16030, and RM520; Venuprasad et al. 2009) and Sub1 (ART5; Septiningsih et al. 2009) was used for foreground selection in Swarna background. A total of 156 polymorphic markers out of a total of 600 were used for the background study. PCR (polymerase chain reaction) amplification was carried out to check and confirm the introgressed loci and the amplicon size was checked on non-denaturing $6 \%$ or $8 \%$ PAGE (polyacrylamide gel electrophoresis) depending on size of amplicon. SYBR SafeTM was used to stain the gel, viewed after $20 \mathrm{~min}$, and allelic profile was recorded. Stepwise and precise selection involving both phenotyping and genotyping strategies were used to select and advance the plants with desired introgressed loci in every generation. The background genotyping of selected Swarna-Sub1 NILs was also done at GSL- IRRI using $6 \mathrm{~K}$ SNP Infinium chip.

\section{Evaluation of NILs in national trials}

In India, in 2015, in All India Coordinate Rice Improvement Project (AICRIP), IR 96322-34-223-B-1-1-1-1 was evaluated along with 17 other introgressed lines and their respective recurrent parents, sensitive checks and donor parents of drought QTLs (IR 81896-B-B-195) in the Advance Variety Trial 1-Near Isogenic Line-Drought and Submergence' (AVT1 NIL-Drt and Sub). The experiment was conducted at six locations (Cuttack, Pusa, Chinsurah, Titabar, Gerua and Ghagharaghat) to evaluate the entries under submergence and normal irrigated conditions. For drought stress as well as control conditions, trials were evaluated at four locations (ICAR-Patna, Varansai, Rewa and Coimbatore). In 2016, the entries that were promising during 2015 that includes IR 96322-34-223-B-1-1-1-1 along with recurrent parents, sensitive checks and donor parents of drought QTLs (IR 81896-B-B-195) were evaluated at eight locations (Maruteru, Chinsurah, Gerua, Moncompu, Pusa, NRRI, Ghaghraghat, Titabar) for submergence and at six locations (Gangavati, Masodha, Mugad, ICAR-Patna, Warangal and Coimbatore) for drought stress. At these locations, experiment was also conducted under normal irrigated conditions.

In both the years and at all locations in both stress and normal situations, the experiment was laid out in three replications in the randomized complete block design (RCBD), following the spacing of $20 \times 15 \mathrm{~cm}$ in a plot size of $15 \mathrm{~m}^{2}$. Sowings under submergence were taken up in the last week of June and plantings in the last week of July to first week of August. Under normal irrigated conditions, sowings were taken up in the last week of June to first week of July and plantings in the last week of July to first week of August. In case of drought stress conditions, sowings were taken up from last week of June to second week of July and plantings from last week of July to second week of August. Fertilizers were applied as $\mathrm{N}: \mathrm{P}_{2} \mathrm{O}_{5}: \mathrm{K}_{2} \mathrm{O}(90: 30: 30) \mathrm{kg} \mathrm{ha}^{-1}$ in control trials. In drought trials, fertilizer dose of 75:30:30 N: $\mathrm{P}_{2} \mathrm{O}_{5}: \mathrm{K}_{2} \mathrm{O}$ was applied. Observations were recorded for days to flowering, days to maturing, plant height $(\mathrm{cm})$, biomass yield $\mathrm{kg} \mathrm{ha}^{-1}$, grain yield $\mathrm{kg} \mathrm{ha}^{-1}$, 
and harvest index. Under drought stress conditions, data was recorded on number of rain free days during crop growth season and stage of crop under drought stress was noted along with the severity of the stress. Protective irrigations were given at critical crop growth stages depending on the severity of the drought imposed as observed from the performance of susceptible checks and the recurrent parents. Under submergence stress, water stagnation of $30-80 \mathrm{~cm}$ was maintained.

A total of 46 Swarna-Sub1 + drought QTLs introgressed NILs were evaluated in three environments namely as control, reproductive drought stage stress and submergence at National Rice Research Program (NRRP, Hardinath, Nepal) during 2014 and 2015. The seeding date was June 19 in 2014 and June 18 in 2015. The twenty-one days old seedlings were transplanted in each trial. Two selected breeding lines, IR 963211447-651-B-1-1-2 and IR 94391-131-358-19-B-1-1-1 were evaluated in the National Coordinated Varietal Trials (NCVT) at Regional Agricultural Research Station, Tarahara, Parwanipur, Nepalgunj, and Lumle, National Maize Research Program, Rampur, National Wheat Research Program, Bhairahawa, under rainfed condition in 2015WS and 2016WS. All the experiments at NRRP Hardinath were laid out in alpha lattice with three replications where as in NCVT, the experiments were laid in RCBD design with two replications. The spacing was $20 \mathrm{~cm}$ between rows and $20 \mathrm{~cm}$ between plants. The plot size was $5 \times 2 \mathrm{~m}^{2}$. Fertilizers were applied as $\mathrm{N}: \mathrm{P}_{2} \mathrm{O}_{5}: \mathrm{K}_{2} \mathrm{O}$ (90:30: 30$) \mathrm{kg} \mathrm{ha}^{-1}$. In drought trials, fertilizer dose of $75: 30: 30 \mathrm{~N}: \mathrm{P}_{2} \mathrm{O}_{5}: \mathrm{K}_{2} \mathrm{O}$ was applied. The submergence trial was subjected to 15 days complete submerge and then field was de-submerged. Seeding of drought stress trail was delayed by 25 days from normal planting so that rainy season terminated with the onset of reproductive stage of the crop. Trench was constructed around trial having the drought experiments to prevent seepage of water from other fields as well as for efficient drainage for drought imposition. In drought trials, tensiometer was installed to monitor soil moisture during the crop in the drought field. Pizzometer was also installed to monitor water table from the drought field. The observations on heading days, plant height $(\mathrm{cm})$, and grain yield were recorded.

\section{Statistical analysis}

\section{Step 1: Single-trial analysis}

Experimental designs across trials varied. For all the experiments with alpha lattice design, the effects of replications and blocks within replication were considered as random and lines as fixed. The model used for alpha lattice (AL) design was:

$$
y_{i j k}=\mu+g_{i}+r_{j}+b_{l j}+e_{i j k}
$$

For the Randomized Complete Block Design (RCBD) was:

$$
\mathrm{y}_{\mathrm{ijk}}=\mu+\mathrm{g}_{\mathrm{i}}+\mathrm{r}_{\mathrm{j}}+\mathrm{e}_{\mathrm{ijk}}
$$

For the augmented RCBD, the model used was:

$$
\mathrm{y}_{\mathrm{ijk}}=\mu+\mathrm{g}_{\mathrm{i}}+\mathrm{b}_{\mathrm{l}}+\mathrm{e}_{\mathrm{ilk}}
$$

where $\mu$ represents overall mean, $g_{i}$ represents the effect of the $i^{\text {th }}$ genotype, $r_{j}$ represents the effect of the $j^{\text {th }}$ replicate, $b_{l j}$ represents the effect of the $l^{t h}$ block within the $j^{\text {th }}$ replicate, $b_{l}$ represents the effect of the $l^{\text {th }}$ block and $e_{i j k}$ is the error.

\section{Step 2: Mean comparison of qDTY and Sub1 combinations}

The performance of the breeding lines nested within the QTL class in the block within the replicate is modeled as follows:

$$
\mathrm{y}_{\mathrm{ijkl}}=\mu+\mathrm{r}_{\mathrm{k}}+\mathrm{b}(\mathrm{r})_{\mathrm{kl}}+\mathrm{q}_{\mathrm{i}}+\mathrm{g}(\mathrm{q})_{\mathrm{ij}}+\mathrm{e}_{\mathrm{ilkl}}
$$

where $\mu$ is the population mean, $r_{k}$ is the effect of the $k^{\text {th }}$ replicate, $b(r)_{k l}+q_{i}$ is the effect of the $l^{\text {th }}$ block within the $k^{\text {th }}$ replicate, $q_{i}$ is the effect of the $i^{\text {th }}$ QTL, $g(q)_{i j}$ is the effect of the $j^{t h}$ genotype nested within the $i^{t h}$ QTL and $e_{i j k l}$ is the error. The effects of QTL and genotypes within QTL are considered fixed while the replicate and blocks within replicate effects are considered random. ANOVA and F test using SAS v9.2 were used to see whether the QTL classes differed significantly from each other.

Step 3: $Q \times E$ interaction model based on genotype means Based on the trial mean grain yield, each experiment was re-classified for the observed drought stress intensity based on the yield reduction compared to non-stress (control) as per Kumar et al. (2009). The trials were classified as non-stress (control); moderate stress (30\% to $65 \%$ yield reduction); severe stress (greater than 65\%); and over-stressed (greater than 85\%). Experiments which were classified as being overstressed were excluded from the analysis due to poor expression of their genetic variability.

The linear model used to study the $\mathrm{Q} \times \mathrm{E}$ interactions for the breeding lines tested across environment was:

$$
\mathrm{y}_{\mathrm{kmj}}=\mu+\mathrm{q}_{\mathrm{k}}+\mathrm{g}(\mathrm{q})_{\mathrm{kj}}+\mathrm{l}_{\mathrm{m}}+\mathrm{ql}_{\mathrm{km}}+\mathrm{g}(\mathrm{ql})_{\mathrm{kmj}}+\mathrm{e}_{\mathrm{kmj}}
$$

Where $y_{k m j}$ is the yield of the $\mathrm{j}^{\text {th }}$ breeding line nested in the $\mathrm{k}^{\text {th }}$ QTL class in the $\mathrm{m}^{\text {th }}$ environment, $\mu$ is the overall mean, $q_{k}$ is the effect of the $\mathrm{k}^{\text {th }}$ QTL class, $g(q)_{k j}$ is the effect of the $\mathrm{j}^{\text {th }}$ line nested in the $\mathrm{k}^{\text {th }}$ QTL class, $l_{m}$ 
is the effect of the $\mathrm{m}^{\text {th }}$ environment, $q l_{k m}$ is the effect of the $\mathrm{k}^{\text {th }}$ QTL class in the $\mathrm{m}^{\text {th }}$ environment, $g(q l)_{k m j}$ $g(q l)_{k m j}$ is the effect of the $\mathrm{j}^{\text {th }}$ line nested in the $\mathrm{k}^{\text {th }}$ QTL class in the $\mathrm{m}^{\text {th }}$ environment, $\in_{k m j} e_{k m j}$ is the random error of the $j^{\text {th }}$ line nested in the $\mathrm{k}^{\text {th }}$ QTL class in the $\mathrm{m}^{\text {th }}$ environment. (Knapp 2001). All effects except the QTL were considered as random.

\section{Graphical representation of the selected NILs}

Graphical representation of the background recovery of NILs using molecular marker data was performed in Graphical Genotypes (GGT 2.0) software (van Berloo 1999). The parent alleles of Swarna-Sub1, Apo, N22, and the heterozygous allele were scored as ' $\mathrm{S}$ ', 'A, ' $\mathrm{B}$ ', and ' $\mathrm{H}$ ', respectively. The estimated proportion of the $\mathrm{S}, \mathrm{A}$, $\mathrm{B}$, and $\mathrm{H}$ alleles in each NIL was calculated using the GGT 2.0.

\section{Additional file}

Additional file 1 : Table S1. Detailed description on experiments with mean values of days to $50 \%$ flowering, plant height and grain yield across different experiments conducted at IRRI and at different location in India and Nepal between 2014 to 2016. Table S2. Comparison of QTL classes for mean grain yield $\left(\mathrm{kg} \mathrm{ha}^{-1}\right)$ across generation advancement under irrigated NS and RS drought stress conditions at IRRI, Philippines. Figure S1. Rainfall data $(\mathrm{mm})$ collected at different experimental sites during the reproductive stage drought stress screening in (A) 2014, (B) 2015, and (C) 2016. (DOCX $373 \mathrm{~kb})$

\section{Acknowledgements}

We thank Ma. Teresa Sta. Cruz and Paul Maturan for the management of field experiments, Jocelyn Guevarra and RuthErica Carpio for assistance with seed preparations.

\section{Funding}

This study was supported by the Bill \& Melinda Gates Foundation (BMGF) and the Deutsche Gesellschaft für Technische Zusammenarbeit (GTZ). The authors thank BMGF and GTZ for financial support for the study.

\section{Availability of data and materials}

The relevant supplementary data has been provided with the manuscript.

\begin{abstract}
Authors' contributions
NS was involved in conducting the experiments at IRRI, analysis, interpretation of the data, and drafting the manuscript, SD and BPM was involved in developing the pyramided lines and conducting experiments at IRRI, AR was involved in analysis and interpretation of data, SK and SPS was involved in conducting experiments in India, RBY was involved in conducting experiments in Nepal, ONS, JNR, AA, SY and CV was involved in conducting experiments in India, AH was involved in conducting experiments at IRRI, SV, NPM, TR and JB was involved in conducting experiments in India, PV was involved in conducting experiments at IRRI, AK conceived the idea of the study and was involved in critical revision and final approval of the version to be published. All authors read and approved the final manuscript.
\end{abstract}

\section{Ethics approval and consent to participate}

Not applicable.

\section{Consent for publication}

The manuscript has been approved by all authors.

\section{Competing interests}

The authors declare that they have no competing interests.

\section{Publisher's Note}

Springer Nature remains neutral with regard to jurisdictional claims in published maps and institutional affiliations.

\section{Author details}

${ }^{1}$ International Rice Research Institute, DAPO Box 7777, Metro Manila, Philippines. ${ }^{2}$ Punjab Agricultural University, Ludhiana, India. ${ }^{3}$ CAR Research Complex for Eastern Region, Patna, Bihar, India. ${ }^{4}$ Bihar Agricultural University, Sabour, Bihar, India. ${ }^{5}$ National Rice Research Program Hardinath, Dhanusha, Nepal. ${ }^{6}$ CAR-National Rice Research Institute, Cuttack, Odisha, India. ${ }^{7}$ International Rice Research Institute, South Asia Hub, ICRISAT, Patancheru, Hyderabad, India. ${ }^{8}$ Indira Gandhi Krishi Vishwavidyalaya, Raipur, Chhattisgarh, India. ${ }^{9}$ Central Rainfed Upland Rice Research station, National Rice Research Institute, Hazaribagh, Jharkhand, India. ${ }^{10}$ ICAR-Indian Institute of Rice Research, Hyderabad, India. ${ }^{11}$ International Maize and Wheat Improvement Centre (CIMMYT), Texcoco, Mexico.

Received: 19 September 2018 Accepted: 11 February 2019

Published online: 18 February 2019

\section{References}

Barnabás B, Jäger K, Fehér A (2008) The effect of drought and heat stress on reproductive processes in cereals. Plant Cell Environ 31(1):11-38

Carlborg Ö, Haley CS (2004) Epistasis: too often neglected in complex trait studies? Nat Rev Genet 5:618-625

Dar MH, Singh S, Singh US, Zaidi NW, Ismail AM (2014) Stress Tolerant Rice Varieties-Making Headway in India. SATSA Mukhaptra Ann Tech Issue 18:1-14

Dar MH, Zaidi NW, Waza SA, Verulkar SB, Ahmed T, Singh PK, Roy SB, Chaudhary B, Yadav R, Islam MM, Iftekharuddaula KM (2018) No yield penalty under favorable conditions paving the way for successful adoption of flood tolerant rice. Sci Rep 8(1):9245

Dilley M, Chen RS, Deichmann U, Lerner-Lam AL, Arnold M (2005) Multihazard exposure analysis. In: Natural disaster hotspots: a global risk analysis. Chapter 5, 47-52. The World Bank and Columbia University, Washington, DC

Dixit S, Singh A, Sandhu N, Bhandari A, Vikram P, Kumar A (2017) Combining drought and submergence tolerance in rice: marker-assisted breeding and QTL combination effects. Mol Breed 37:143

Dixit S, Singh A, Sta Cruz MT, Maturan PT, Amante M, Kumar A (2014) Multiple major QTL lead to stable yield performance of rice cultivars across varying drought intensities. BMC Genet 15:16

Fukao T, Yeung E, Bailey-Serres J (2011) The Submergence Tolerance Regulator SUB1A Mediates Crosstalk between Submergence and Drought Tolerance in Rice. Plant Cell 23:412-427

Ghimire KH, Quiatchon LA, Vikram P, Swamy BM, Dixit S, Ahmed H, Hernandez JE, Borromeo TH, Kumar A (2012) Identification and mapping of a QTL ( $\left.9 D T T_{1,3}\right)$ with a consistent effect on grain yield under drought. Field Crop Res 131:88-96

Gumma MK, Gauchan D, Nelson A, Pandey S, Rala A (2011) Temporal changes in rice-growing area and their impact on livelihood over a decade: A case study of Nepal. Agric Ecosyst Environ 142(3-4):382-392

Henry A, Dixit S, Mandal NP, Anantha MS, Torres R, Kumar A (2014) Grain yield and physiological traits of rice lines with the drought yield QTL $9 D T Y_{12.1}$ showed different responses to drought and soil characteristics in upland environments. Function Plant Bio 41(11):1066-1077

Henry A, Swamy BM, Dixit S, Torres RD, Batoto TC, Manalili M, Anantha MS, Mandal NP, Kumar A (2015) Physiological mechanisms contributing to the QTL-combination effects on improved performance of IR64 rice NILs under drought. J Exp Bot 66(7):1787-1799

IRRI (2002) Standard Evaluation System for Rice (SES), vol 4. International Rice Research Institute (IRRI), Los Banos, pp 15-16

Knapp SJ (2001) Mapping quantitative trait loci. In: Philipps RL, Vasil IK (eds) DNA based markers in plants, pp 58-96

Kretzschmar T, Pelayo MAF, Trijatmiko KR, Gabunada LFM, Alam R, Jimenez R, Mendioro MS, Slamet-Loedin IH, Sreenivasulu N, Bailey-Serres J, Ismail AM (2015) A trehalose-6-phosphate phosphatase enhances anaerobic germination tolerance in rice. Nat Plants 1(9):15124

Kumar A, Dixit S, Ram T, Yadaw RB, Mishra KK, Mandal NP (2014) Breeding highyielding drought-tolerant rice: genetic variations and conventional and molecular approaches. J Exp Bot 65(21):6265-6278 
Kumar A, Sandhu N, Dixit S, Yadav S, Swamy BPM, Shamsudin NAA (2018) Marker-assisted selection strategy to pyramid two or more QTLs for quantitative trait-grain yield under drought. Rice 11:35

Kumar A, Verulkar S, Dixit S, Chauhan B, Bernier J, Venuprasad R, Zhao D, Shrivastava MN (2009) Yield and yield-attributing traits of rice (Oryza sativa L.) under lowland drought and suitability of early vigor as a selection criterion. Field Crop Res 114(1):99-107

Lafitte HR, Price AH, Courtois B (2004) Yield response to water deficit in an upland rice mapping population: associations among traits and genetic markers. Theor App Genet 109(6):1237-1246

Lesk C, Rowhani P, Ramankutty N (2016) Influence of extreme weather disasters on global crop production. Nature 529(7584):84

Lobell DB, Bänziger M, Magorokosho C, Vivek B (2011) Nonlinear heat effects on African maize as evidenced by historical yield trials. Nat Clim Chang 1(1):42

Magneschi L, Perata P (2009) Rice germination and seedling growth in the absence of oxygen. Ann Bot 103:181-196

Mottaleb KA, Gumma MK, Mishra AK, Mohanty S (2015) Quantifying production losses due to drought and submergence of rainfed rice at the household level using remotely sensed MODIS data. Agric Syst 137:227-235

Murray HG, Thompson WF (1980) Rapid isolation of high molecular weight DNA. Nucleic Acids Res 8:4321-4325

Neeraja CN, Maghirang-Rodriguez R, Pamplona A, Heuer S, Collard BC, Septiningsih EM, Vergara G, Sanchez D, Xu K, Ismail AM, Mackill DJ (2007) A marker-assisted backcross approach for developing submergence-tolerant rice cultivars. Theor App Genet 115(6):767-776

Pandey S, Bhandari H (2007) Analytical Framework. In: Economic Costs of Drought and Rice Farmers' Coping Mechanisms. International Rice Research Institute, Los Baños

Pandey S, Bhandari H (2008) Drought economic costs and research implications. In: Serraj R, Bennett J, Hardy B (eds) Drought frontiers in rice: crop improvement for increased rainfed production. International Rice Research Institute, World Scientific, Singapore and Los Baños, pp 3-17

Sandhu N, Kumar A (2017) Bridging the rice yield gaps under Drought: QTLs, genes, and their use in breeding programs. Agronomy 7(2):27

Sandhu N, Singh A, Dixit S, Cruz MTS, Maturan PC, Jain RK, Kumar A (2014) Identification and mapping of stable QTL with main and epistasis effect on rice grain yield under upland drought stress. BMC Genet 15(1):63

Septiningsih EM, Hidayatun N, Sanchez DL, Nugraha Y, Carandang J, Pamplona AM, Collard BC, Ismail AM, Mackill DJ (2015) Accelerating the development of new submergence tolerant rice varieties: the case of Ciherang-Sub1 and PSB Rc18-Sub1. Euphytica 202(2):259-268

Septiningsih EM, Pamplona AM, Sanchez DL, Neeraja CN, Vergara GV, Heuer S, Ismail AM, Mackill DJ (2009) Development of submergence-tolerant rice cultivars: the Sub1 locus and beyond. Ann Bot 103(2):151-160

Shamsudin NAA, Swamy BM, Ratnam W, Cruz MTS, Sandhu N, Raman AK, Kumar A (2016) Pyramiding of drought yield QTLs into a high-quality Malaysian rice cultivar MRQ74 improves yield under reproductive stage drought. Rice 9(1):21

Singh S, Mackill DJ, Ismail AM (2014) Physiological basis of tolerance to complete submergence in rice involves genetic factors in addition to the SUB1 gene. AoB Plants 6:1-20

Singh SP, Jain A, Anantha MS, Tripathi S, Sharma S, Kumar S, Prasad A, Sharma B, Karmakar B, Bhattarai R, Das SP, Singh SK, Shenoy V, Babu RC, Robin S, Swain P, Dwivedi JL, Yadaw RB, Mandal NP, Ram T, Mishra KK, Verulkar SB, Aditya T, Prasad K, Perraju P, Krishna RM, Sharma S, Anitha KR, Kumar A, Henry A (2017) Depth of soil compaction predominantly affects rice yield reduction by reproductive-stage drought at varietal screening sites in Bangladesh, India, and Nepal. Plant Soil 417(1-2):377-392

Toledo AMU, Ignacio JCl, Casal C, Gonzaga ZJ, Mendioro MS, Septiningsih EM (2015) Development of improved Ciherang-Sub1 having tolerance to anaerobic germination conditions. Plant Breed Biotech 3(2):77-87

van Berloo R (1999) Computer note. GGT: software for the display of graphical genotypes. J Heredity 90(2):328-329

Venuprasad R, Dalid CO, Del Valle M, Zhao D, Espiritu M, Cruz MS, Amante M, Kumar A, Atlin GN (2009) Identification and characterization of large-effect quantitative trait loci for grain yield under lowland drought stress in rice using bulk-segregant analysis. Theor App Genet 120(1):177-190

Vikram P, Swamy BM, Dixit S, Ahmed HU, Cruz MTS, Singh AK, Kumar A (2011) qDTY 1.1 , a major QTL for rice grain yield under reproductive-stage drought stress with a consistent effect in multiple elite genetic backgrounds. BMC Genet 12(1):89
Vikram P, Swamy BM, Dixit S, Trinidad J, Cruz MTS, Maturan PC, Amante M, Kumar A (2016) Linkages and interactions analysis of major effect drought grain yield QTLs in rice. PLoS One 11(3):e0151532

Xing Y, Tan Y, Hua JP, Sun X, Xu C, Zhang Q (2002) Characterization of the main effects, epistatic effects and their environmental interactions of QTLs on the genetic basis of yield traits in rice. Theor App Genet 105(2-3):248-257

Xu K, Mackill DJ (1996) A major locus for submergence tolerance mapped on rice chromosome 9. Mol Breed 2(3):219-224

\section{Submit your manuscript to a SpringerOpen ${ }^{\circ}$ journal and benefit from:}

- Convenient online submission

- Rigorous peer review

- Open access: articles freely available online

- High visibility within the field

- Retaining the copyright to your article

Submit your next manuscript at $\boldsymbol{\nabla}$ springeropen.com 